\title{
The removal of organic compounds from landfill leachate using ozone-based advanced oxidation processes
}

\author{
Jacek Leszczyński ${ }^{1, *}$, Maria, Jolanta Walery ${ }^{1}$ \\ ${ }^{1}$ Bialystok University of Technology, 45E Wiejska Str., 15-351 Białystok, Poland
}

\begin{abstract}
In this study, the application of ozonation and ozonation with hydrogen peroxide processes for landfill leachate treatment was investigated. The effluents were characterized by COD $710 \mathrm{mgO}_{2} / \mathrm{dm}^{3}$ and $\mathrm{BOD}_{5} 72 \mathrm{mg} \mathrm{O} / \mathrm{dm}^{3}$. According to the adopted indicators, the determined $\mathrm{BOD} / \mathrm{COD}$ ratio of 0.1 in raw leachates indicates a stabilized landfill. Ozone was applied at doses of $0.15-0.6 \mathrm{gO}_{3} / \mathrm{dm}^{3}$, and hydrogen peroxide at such doses to keep the weight ratios of $\mathrm{H}_{2} \mathrm{O}_{2} / \mathrm{O}_{3} 0.4-1.6$. The maximum COD and UV absorbance removal was respectively $29 \%$ and $51 \%$ by applying a high ozone dose of $0.6 \mathrm{gO}_{3} / \mathrm{dm}^{3}$. After oxidation, the ratio of $\mathrm{BOD} / \mathrm{COD}$ was increased from 0.1 up to 0.3 . It has been shown that by using hydrogen peroxide in ozonation, organic compounds expressed as COD can be efficiently removed from the effluents. The best conditions for the $\mathrm{H}_{2} \mathrm{O}_{2} / \mathrm{O}_{3}$ process were obtained with a $\mathrm{H}_{2} \mathrm{O}_{2} / \mathrm{O}_{3}$ ratio of 0.8 and ozone dose of $0.6 \mathrm{gO}_{3} / \mathrm{dm}^{3}$. Under these conditions, the removal efficiency of COD was $46 \%$.
\end{abstract}

\section{Introduction}

Ozone is a strong oxidant that reacts at ambient temperature with most organic compounds, either directly by electrophilic attack of the ozone molecule, or indirectly by generating 'OH radicals [1]. The direction and course of these reactions mainly depends on the $\mathrm{pH}$. Under basic conditions, $\mathrm{OH}^{-}$ions react with ozone leading to the formation of intermediates, such as ions $\left({ }^{\circ} \mathrm{O}_{2}^{-}\right)$and $\left(\mathrm{HO}_{2}{ }^{\circ}\right)$, that accelerate its decomposition [2]:

$$
\begin{aligned}
& \mathrm{O}_{3}+\mathrm{OH}^{-} \rightarrow \mathrm{O}^{-}+\mathrm{HO}_{2}{ }^{-} \\
& \mathrm{O}_{3}+\mathrm{O}_{2}^{-} \rightarrow \mathrm{O}_{3}^{-}+\mathrm{O}_{2}
\end{aligned}
$$

The ozonation process is used, among others, for the treatment of leachates from stabilized landfills in combination with sorption, coagulation, as well as biological processes, the operation time of which exceeds 5 years. In these types of landfills, organic compounds that are harder to biodegrade prevail. In addition, leachate from these landfills

\footnotetext{
* Corresponding author: jleszczynski@pb.edu.pl
} 
is characterized by a stabilized composition, high ammonium nitrogen content and a $\mathrm{BOD} / \mathrm{COD}$ ratio below $0.1[3,4,5]$.

As a result of ozone treatment, a part of organic compounds undergoes transformation into more readily biodegradable forms, which enables their further purification by biological methods. In this case, an increase in the BOD/COD ratio is observed, thus the share of biodegradable fractions in the effluents increases. Under the influence of ozone, organic compounds, which are not biodegradable, are also oxidized. The final product is usually acetic and oxalic acid. With the use of lower doses of ozone, the disruption of bonds in macromolecular compounds can lead to the formation of alcohols, aldehydes and ketones $[6,7,8]$. In addition to removing the organic compounds, ozonation also reduces the color of landfill leachates and eliminates odor nuisance [2].

Ozonation, in combination with hydrogen peroxide, belongs to the so-called advanced oxidation processes, in which highly reactive free ${ }^{\circ} \mathrm{OH}$ radicals are generated that can increase the effectiveness of ozone action. This method eliminates many pollutants that in practice do not react only with the ozone [9]. However, in comparison to ozone, ${ }^{\circ} \mathrm{OH}$ radicals act non-selectively, additionally in the presence of $\mathrm{HCO}_{3}{ }^{-}$and $\mathrm{CO}_{3}{ }^{2-}$ ions, they are quickly decomposed. Amongst advanced oxidation methods, in which ${ }^{\circ} \mathrm{OH}$ radicals are generated, $\mathrm{O}_{3} / \mathrm{UV}, \mathrm{H}_{2} \mathrm{O}_{2} / \mathrm{UV}, \mathrm{O}_{3} / \mathrm{H}_{2} \mathrm{O}_{2} / \mathrm{UV}$, catalysts such as $\mathrm{TiO}_{2}$ and the process of Fenton and photo-Fenton, are also used for landfill leachate and wastewater purification $[10,11,12]$.

During ozonation, in combination with hydrogen peroxide, ${ }^{\circ} \mathrm{OH}$ radicals are formed as a result of the reaction of ozone with the hydroperoxide ion formed after the dissociation of hydrogen peroxide [2]:

$$
\begin{gathered}
\mathrm{H}_{2} \mathrm{O}_{2} \leftrightarrow \mathrm{H}^{+}+\mathrm{HO}_{2}^{-} \\
\mathrm{O}_{3}+\mathrm{HO}_{2}^{-} \rightarrow \mathrm{O}_{2}+\mathrm{O}^{2-\cdot}+{ }^{\cdot} \mathrm{OH}
\end{gathered}
$$

Due to the varied composition and high loads of organic pollutants, membrane processes such as reverse osmosis and ultrafiltration are also applied for the treatment of landfill leachates. Due to high costs, good results are obtained through the pre-treatment of leachate prior to membrane methods, e.g. in the process of filtration, coagulation and sorption on activated carbon [13].

The aim of the study was to compare the effectiveness of the removal of organic compounds from landfill leachates expressed by the COD indicator using ozone and ozone with hydrogen peroxide.

\section{Material and analytical methods}

The research was carried out upon leachates from a landfill located in the north-eastern part of Poland using a laboratory ozone generator and $30 \% \mathrm{H}_{2} \mathrm{O}_{2}$. The $\mathrm{pH}$, electrolytic conductivity, color, turbidity, suspension, $\mathrm{UV}_{254}$ absorbance, chemical oxygen demand (COD), biochemical oxygen demand $\left(\mathrm{BOD}_{5}\right)$, ammonium nitrogen and TOC, were determined in raw leachates for technological research. Analytical tests were carried out according to Standard Method APHA, unless otherwise stated [14]. A Hach Sension $4 \mathrm{pH}-$ meter was used to determine the $\mathrm{pH}$ and conductivity, the $\mathrm{BOD}_{5}$ was determined with an Oxitop kit, turbidity with a Hach nephelometer, and UV absorbance with a UV-Vis spectrophotometer - Pharo 300 in a $1 \mathrm{~cm}$ cuvette at $254 \mathrm{~nm}$ wavelength. The color was determined on a platinum-cobalt scale with the use of a spectrophotometer.

The ozone concentration in the air-ozone mixture was determined using the iodometric method proposed by IOA [15]. Hydrogen peroxide was also determined using the iodometric method [16]. 
The content of organic compounds in leachate samples after the ozonation process and ozonation with the addition of hydrogen peroxide was expressed by the COD indicator. The presented COD values take into account the correction due to the presence of hydrogen peroxide according to the formula recommended by Kang at al. [17].

The presented test results are the average of three replicates. The standard deviation of measured values did not exceed $5 \%$.

The removal efficiency of COD was calculated using the following equation:

$$
R=\frac{\left(C_{i}-C_{f}\right) \cdot 100}{C_{i}} \%
$$

where $C_{i}$ and $C_{f}$ refer to the COD in the landfill leachate before and after the reaction, respectively.

\section{Experimental Procedures}

The ozonation system consisted of a pneumatic Triligaz ozone generator with a maximum capacity of $8 \mathrm{~g} / \mathrm{h}$ and a glass bubble chamber with a diameter of $5 \mathrm{~cm}$ and a total height of $90 \mathrm{~cm}$. The air and ozone mixture was continuously supplied through a ceramic diffuser with a diameter of $35 \mathrm{~mm}$. In order to ensure the homogeneous distribution of gas to the liquid phase, the contents of the chamber were additionally stirred using a magnetic stirrer. Tests were carried out with an air-ozone mixture flow of $1.0 \mathrm{~L} / \mathrm{min}$ and an ozone concentration of $10 \mathrm{~g} / \mathrm{m}^{3}$. In each series of tests, the volume of leachate was $1 \mathrm{~L}$. The ozone dose in the range from 0.15 to $0.6 \mathrm{~g} / \mathrm{L}$ was determined using the appropriate ozonation time. Hydrogen peroxide was dosed in amounts depending on the dose of ozone, keeping the ratio of $\mathrm{H}_{2} \mathrm{O}_{2} / \mathrm{O}_{3}$ at the level of 0.4-1.6.

\section{Results and Discussion}

\subsection{Leachate characteristics}

The physicochemical parameters of leachates for technological tests are presented in Table 1. A characteristic feature of the leachate tested is the relatively high COD value with a low $\mathrm{BOD}$ value. The calculated $\mathrm{BOD} / \mathrm{COD}$ ratio value of 0.1 indicates the type of stable storage. According to the adopted indicators, a BOD/COD ratio below 0.12 in raw leachates indicates this type of landfill [18]. The research also draws attention to the fact that leachates from stabilized landfills show higher $\mathrm{pH}$ values, usually above 7 [7]. The tested leachates were characterized by $\mathrm{pH} 8.26$, COD $710 \mathrm{mg} / \mathrm{L}, \mathrm{BOD}_{5} 72 \mathrm{mg} / \mathrm{L}$ and turbidity $2 \mathrm{NTU}$ as well as intensive color $1130 \mathrm{mgPt} / \mathrm{L}$.

Table 1. Characteristic of landfill leachate.

\begin{tabular}{|c|c|}
\hline Parameter & Value \\
\hline $\mathrm{pH}$ & 8.26 \\
\hline Color (Pt-Co units) & 1130 \\
\hline COD $(\mathrm{mg} / \mathrm{L})$ & 710 \\
\hline BOD $(\mathrm{mg} / \mathrm{L})$ & 72 \\
\hline
\end{tabular}




\begin{tabular}{|c|c|}
\hline TOC $(\mathrm{mg} / \mathrm{L})$ & 205 \\
\hline $\mathrm{UV}_{254}$ absorbance $\left(\mathrm{cm}^{-1}\right)$ & 0.310 \\
\hline Turbidity $(\mathrm{NTU})$ & 2 \\
\hline Conductivity $(\mathrm{mS} / \mathrm{cm})$ & 6.9 \\
\hline $\mathrm{NH}_{4}{ }^{-}-\mathrm{N}(\mathrm{mgN} / \mathrm{L})$ & 152.5 \\
\hline
\end{tabular}

\subsection{Ozonation and $\mathrm{O}_{3} / \mathrm{H}_{2} \mathrm{O}_{2}$}

Changes in the COD value in effluents subjected to the ozonation process depending on the dose of ozone and hydrogen peroxide are shown in Figure 1. The experiment was carried out in effluents at $\mathrm{pH} 8.26$. According to research carried out by Cortez et al., higher $\mathrm{pH}$ values increase the number of ozone molecules that are decomposed to form ${ }^{\circ} \mathrm{OH}$ radicals with a high redox potential, which may increase the efficiency of removing pollutants [3].

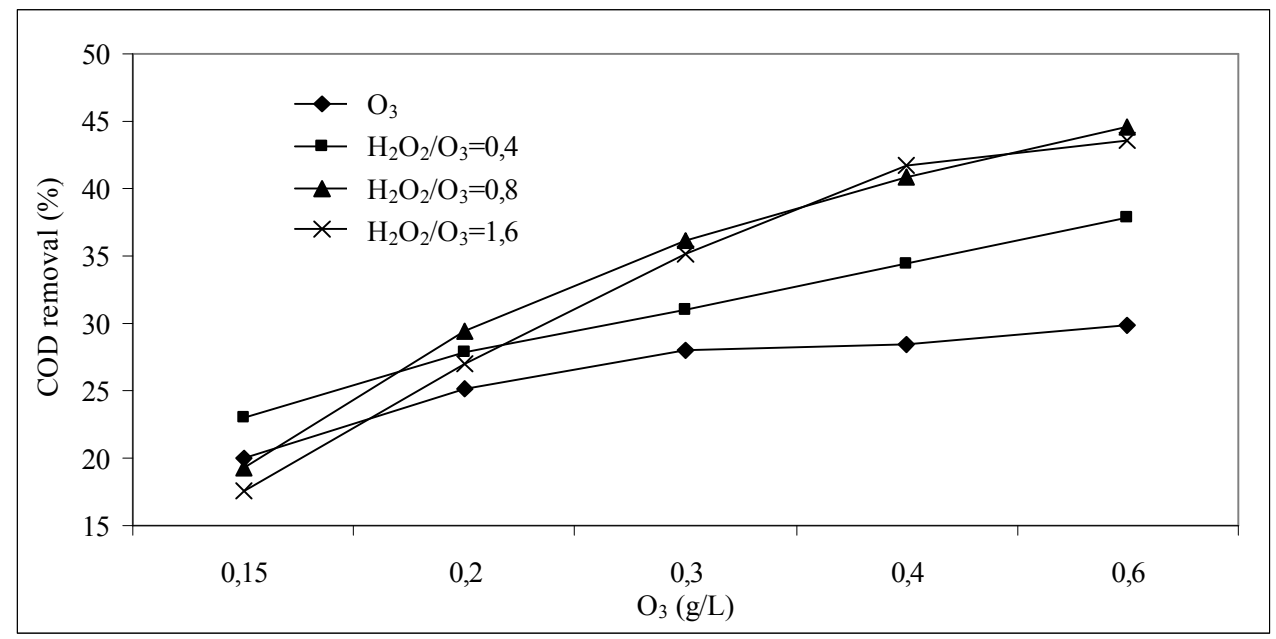

Fig. 1. COD removal at different ozone and hydrogen peroxide doses.

After the ozonation process, the value of impurities expressed as COD varied depending on the ozone dose ranging from $568 \mathrm{mg} / \mathrm{L}$ to $498 \mathrm{mg} / \mathrm{L}$.

The highest value of the COD reduction was recorded with the ozonation time of 60 minutes and the ozone dose of $0.6 \mathrm{~g} / \mathrm{L}$. In this case, the value of the removed COD was 212 $\mathrm{mg} / \mathrm{L}$, which ensured the effect of this indicator removal at the level of $29.9 \%$. The COD value gradually decreased with the increase of the ozone dose, but the highest increase of COD removal effect $(28.1 \%)$ in the range of the $\mathrm{O}_{3}$ doses applied, was recorded at the ozone dose of $0.3 \mathrm{~g} / \mathrm{L}$. At the lowest ozone dose of $0.15 \mathrm{gO}_{3} / \mathrm{L}$, the COD removal effect was very low and amounted to only $20 \%$.

As a result of the leachate ozonation, an increase in the BOD/COD ratio was recorded in each case, regardless of the ozone dose used. The BOD value at the shortest and the longest contact time ranged from $57 \mathrm{mg} / \mathrm{L}$ to $149 \mathrm{mg} / \mathrm{L}$. Thus, the BOD/COD ratio increased from 0.1 at the lowest dose of ozone to 0.3 at the highest dose. Changes in the BOD/COD value depending on the ozone dose are shown in Figure 2.

Bila et al., when ozonizing leachates containing COD $3100 \mathrm{mg} / \mathrm{L}$, BOD $130 \mathrm{mg} / \mathrm{L}$ using ozone doses of $0.5,1.5$ and $3.0 \mathrm{gO}_{3} / \mathrm{L}$, achieved a decrease in COD by $8 \%, 15 \%$ and about $50 \%$, respectively, thus the $\mathrm{BOD} / \mathrm{COD}$ ratio increased to 0.14 at $0.5 \mathrm{gO}_{3} / \mathrm{L}$, to 0.25 at 1.5 
$\mathrm{gO}_{3} / \mathrm{L}$ and to 0.3 at the highest ozone concentration, i.e. $3.0 \mathrm{gO}_{3} / \mathrm{L}$ [19]. A study performed by Cortez et al. revealed an increase in BOD/COD from 0.1 to 0.17 . In turn, according to $\mathrm{Wu}$ et al., applying $1.2 \mathrm{~g} / \mathrm{L}$ dose caused an increase of BOD/COD ratio from 0.06 to 0.5 $[3,20]$.

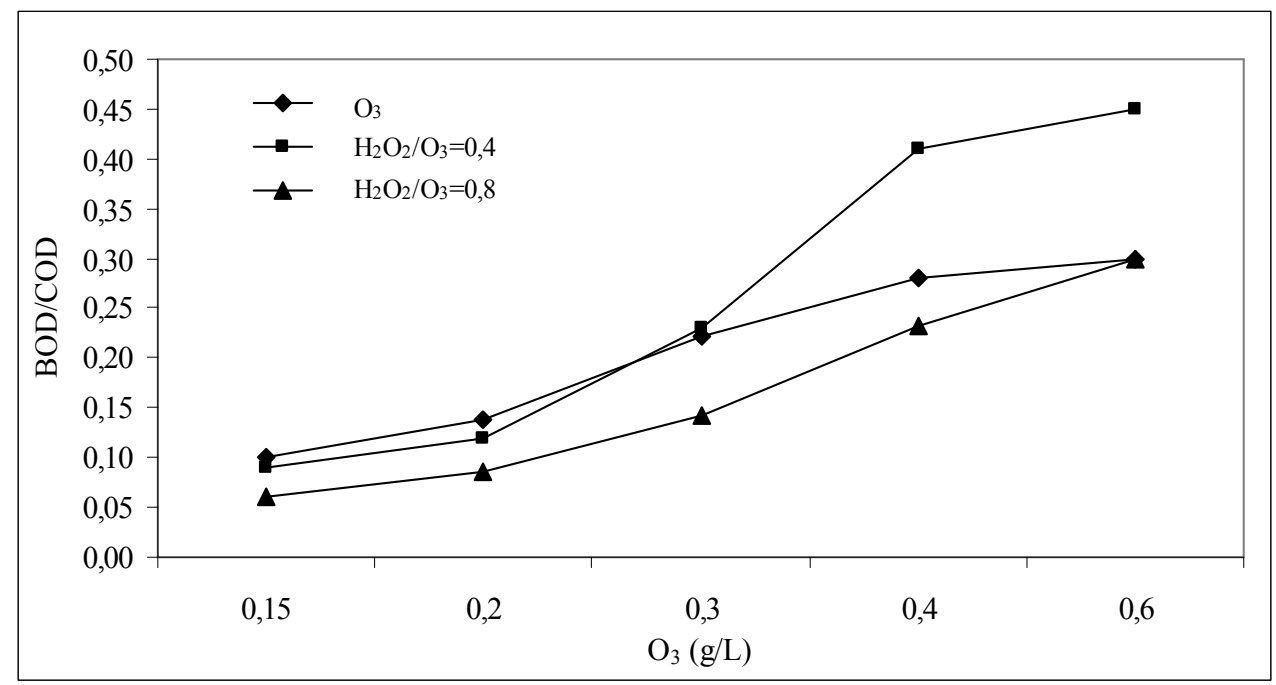

Fig. 2. Effect of ozone and $\mathrm{H}_{2} \mathrm{O}_{2}$ dose on $\mathrm{BOD} / \mathrm{COD}$ ratio.

Compared with the action of ozone alone, the process of oxidation together with hydrogen peroxide has shown an increase in the efficiency of COD removal. Only at the lowest ozone dose of $0.15 \mathrm{~g} / \mathrm{L}$ and $\mathrm{H}_{2} \mathrm{O}_{2} / \mathrm{O}_{3}$ ratios of 0.8 and 1.6 , ozonation turned out to be more effective, especially at the highest dose of $\mathrm{H}_{2} \mathrm{O}_{2}$. The strongest effect of COD removal (29\%) at this ozone dose was recorded with an $\mathrm{H}_{2} \mathrm{O}_{2} / \mathrm{O}_{3}$ ratio $=0.4$. In the remaining range of the oxidants doses used, the COD removal effect successively increased with the dose of ozone and hydrogen peroxide. The highest efficiency of COD reduction when applying various ozone doses, i.e. $0.2,0.3,0.4$ and $0.6 \mathrm{~g} / \mathrm{L}$, amounted respectively to $29.5 \%$ and $36.2 \%$ at $\mathrm{H}_{2} \mathrm{O}_{2} / \mathrm{O}_{3}=0.8,41.7 \%$ at $\mathrm{H}_{2} \mathrm{O}_{2} / \mathrm{O}_{3}=1.6$ as well as $43.6 \%$ at the highest ozone dose and $\mathrm{H}_{2} \mathrm{O}_{2} / \mathrm{O}_{3}$ ratio $=0.8$. A similar effectiveness of COD reduction was recorded at $\mathrm{H}_{2} \mathrm{O}_{2} / \mathrm{O}_{3}=0.8$. At the same time, a much worse effect of lowering the COD indicator was noted at the ozone doses 0.4 and $0.6 \mathrm{~g} / \mathrm{L}$ and the lowest hydrogen peroxide dose, i.e. at $\mathrm{H}_{2} \mathrm{O}_{2} / \mathrm{O}_{3}=0.4$. In this case, the effect of COD removal was only $34.4 \%$ and $37.8 \%$.

The increase of biodegradability expressed as BOD/COD dependence in the process of ozonation with hydrogen peroxide was only recorded at ozone doses of $0.3,0.4$ and $0.6 \mathrm{~g} / \mathrm{L}$ and $\mathrm{H}_{2} \mathrm{O}_{2} / \mathrm{O}_{3}$ ratio $=0.4$. The $\mathrm{BOD} / \mathrm{COD}$ value in this range of oxidants doses amounted to $0.23,0.41$ and 0.45 , respectively. In the case of a larger dose of $\mathrm{H}_{2} \mathrm{O}_{2}$, the BOD/COD value was similar to that of the only-ozone-use process and it was 0.3 .

According to studies conducted by Naumczyk et al., optimal conditions for COD removal were obtained with an ozone dose of $750 \mathrm{mg} / \mathrm{L}$ and a dose of hydrogen peroxide up to $2000 \mathrm{mg} / \mathrm{L}$. The decrease in COD after 60, 120, 240 and $360 \mathrm{~min}$. was 44.8, 67.1, 87.0 and $89.9 \%$ respectively, and with similar response time of $60 \mathrm{~min}$., it was at a similar level [12]. 


\section{Conclusion}

In studies using the ozonation process, the effectiveness of COD removal ranged from $20 \%$ to $20.9 \%$. In the process of self-ozonation, the highest efficiency of COD reduction $(20.9 \%)$ was obtained with the highest dose of ozone, i.e. $0.8 \mathrm{gO}_{3} / \mathrm{L}$. Such a high dose of ozone required to remove a relatively small COD value means that treating leachate with this method is quite expensive. An important advantage of the ozonation process is the increase in $\mathrm{BOD} / \mathrm{COD}$ ratio. As compared to raw leachates, the $\mathrm{BOD} / \mathrm{COD}$ value after ozonation increased to 0.3 , which may increase the effectiveness of leachate treatment with biological methods. In the process of ozonation together with hydrogen peroxide, an increase in $\mathrm{BOD} / \mathrm{COD}$ ratio was recorded only at ozone doses of $0.3,0.4$ and $0.6 \mathrm{~g} / \mathrm{L}$ and $\mathrm{H}_{2} \mathrm{O}_{2} / \mathrm{O}_{3}$ ratio $=0.4$. The largest $\mathrm{BOD} / \mathrm{COD}$ value, in this case, was 0.45 . The highest removal efficiency of COD (44.6\%) in the process with $\mathrm{H}_{2} \mathrm{O}_{2} / \mathrm{O}_{3}$ was recorded at an ozone dose of $0.6 \mathrm{~g} / \mathrm{L}$ and $\mathrm{H}_{2} \mathrm{O}_{2} / \mathrm{O}_{3}$ ratio $=0.8$.

\section{References}

1. M.S. Lucas, J.A. Peres, G. Li Puma. Treatment of winery wastewater by ozonebased advanced oxidation processes $\left(\mathrm{O}_{3}, \mathrm{O}_{3} / \mathrm{UV}\right.$ and $\left.\mathrm{O}_{3} / \mathrm{UV} / \mathrm{H}_{2} \mathrm{O}_{2}\right)$ in a pilot-scale bubble column reactor and process economics. Sep. Purif. Technol 72, 235-241 (2010)

2. T.A. Kurniawan, W.H. Lo, G.Y.S. Chan. Radicals catalyzed oxidation reactions for degradation of recalcitrant compounds from landfill leachate. Chem. Eng. J 125 (1), 35-57 (2006)

3. S. Cortez, P. Teixeira, R. Oliveira, M. Mota. Ozonation as polishing treatment of mature landfill leachate. J. Hazard. Mater 182, 730-734 (2010)

4. J.L. Morais, P.P. Zamora. Use of advanced oxidation process to improve the biodegradability of mature landfill leachate. J. Hazard. Mater 123, 181-186 (2005)

5. P. Haapea, S. Korhonen, T. Tuhkanen. Treatment of industrial landfill leachates by chemical and biological methods: ozonation, ozonation + hydrogen peroxide, hydrogen peroxide and biological post-treatment for ozonated water. Ozone Sci. Eng 24, 369378 (2002)

6. S. Cortez, P. Teixeira, R. Oliveira, M. Mota. Evaluation of Fenton and ozone-based advanced oxidation processes as mature landfill leachate pre-treatments. J. Environ. Manage 92, 749-755 (2011)

7. F. Wang, D.W. Smith, M. Gamal El-Din. Application of advanced oxidation methods for landfill leachate treatment - A review. J. Envir. Eng. Sci 2, 413-427 (2003)

8. D. Kulikowska. Charactarization of organics and methods treatment of leachate from stabilized municipal landfills, Ecol. Chem. Eng. S 16 (3), 389-402 (2009)

9. J. Naumczyk, I. Prokurat, P. Marcinowski. Landfill leachates treatment by $\mathrm{H}_{2} \mathrm{O}_{2} / \mathrm{UV}$, $\mathrm{O}_{3} / \mathrm{H}_{2} \mathrm{O}_{2}$, modified Fenton, and modified photo-Fenton methods. Int. J. Photoenergy 2012, 1-9 (2012)

10. J. Koc-Jurczyk, L. Jurczyk. The efficiency of landfill leachate treatment using the Fenton's reagent. J. Ecol. Eng 16 (3) 70-76 (2015)

11. K. Barbusinski, B. Pieczykolan. COD removal from landfill leachate using fenton oxidation and coagulation. Archit. Civil Eng. Environ 3 (4) 93-100 (2010)

12. D. Krzemińska, E. Neczaj, K. Parkitna. Application of Fenton Reaction for Supporting Biological Wastewater Treatment from the Dairy Industry. Rocznik Ochrona Środowiska 15, 2381-2397 (2013) 
13. R. Nowak, M. Włodarczyk-Makuła, E. Wiśniowska, K. Grabczak. The Comparison of the Effectiveness of Pre-treatment Processes of Landfill Leachate. Rocznik Ochrona Środowiska 18, 122-133 (2016)

14. APHA. Standard methods for the examination of water and wastewater. 20th edition, Washington, DC (1999)

15. International Ozone Association, Standardisation Committee-Europe: Iodometric Method for the Determination of Ozone in a Process Gas, 001/87 (1987)

16. N.V. Klassen, D. Marchington, H.C.H. McGowan. $\mathrm{H}_{2} \mathrm{O}_{2}$ determination by the $\mathrm{I}_{3}{ }^{-}$ method and by $\mathrm{KMnO}_{4}$ titration. Anal. Chem 66 (18) 2921-2925 (1994)

17. Y.W. Kang, M.J. Cho, K.Y. Hwang, Correction of hydrogen peroxide interference on standard chemical oxygen demand test. Water Res 5 1247-1251 (1998)

18. K. Kang, K. Shin, H. Park. Characterization of humic substances present in landfill leachates witch landfill ages and its implications. Water. Res 36, 4023- 4032 (2002)

19. D.M. Bila, A.F. Montalvao, A.C. Silva, M. Dezotti. Ozonation of landfill leachate: evaluation of toxicity removal and biodegradability improvement. J. Hazard. Mater B117, 235-242 (2005)

20. J. Wu, C.C. Wu, H.W. Ma, C.C. Chang. Treatment of landfill leachate by ozone-based advanced oxidation processes. Chemosphere 54, 997-1003 (2004) 